\title{
The $\operatorname{arc} A B C$ Operon Required for Fermentative Growth of Pseudomonas aeruginosa on Arginine: Tn5-751-assisted Cloning and Localization of Structural Genes
}

\author{
By ERNST LÜTHI, ${ }^{1}$ ANNICK MERCENIER ${ }^{2}$ AND DIETER HAAS ${ }^{*}$ * \\ ${ }^{1}$ Mikrobiologisches Institut, Eidgenössische Technische Hochschule, CH-8092 Zürich, Switzerland \\ ${ }^{2}$ Transgène SA, F-67000 Strasbourg, France
}

(Received 14 April 1986; revised 2 June 1986)

\begin{abstract}
Pseudomonas aeruginosa is able to utilize L-arginine as the energy source for growth under anaerobic, nitrate-free conditions. Mutations in the chromosomal $\operatorname{arcABC}$ gene cluster specifying the inducible arginine deiminase pathway enzymes abolish fermentative growth on arginine. From two different arc:: Tn5-751 insertion mutants of $P$. aeruginosa recombinant plasmids have been derived which carry a resistance marker of transposon Tn5-751 plus flanking parts of the arc region. These recombinant plasmids served to reconstruct in vitro the functional $\operatorname{arc} A B C$ cluster on a $5.6 \mathrm{~kb}$ fragment, which was inserted into the broad-host-range vector pK T240. In $P$. aeruginosa this $5.6 \mathrm{~kb}$ segment complemented arc $A B C$ mutations in trans and contained the control region necessary in cis for arc enzyme induction by oxygen limitation and arginine. The results of subcloning experiments and transcriptional lac $Z$ fusions, the polarity of transposon insertions and the effect of external promoters led to the conclusion that the structural genes $\operatorname{arc} A$ (for arginine deiminase), $\operatorname{arcB}$ (for catabolic ornithine carbamoyltransferase) and $\operatorname{arcC}$ (for carbamate kinase) are contiguous and transcribed in the same direction. Thus, the $\operatorname{arc} A B C$ cluster appears to have the characteristics of an operon. In Escherichia coli the cloned $\operatorname{arc} A B C$ genes were expressed at low, non-inducible levels; strong vector promoters enhanced arc expression up to 100 -fold. This indicates that transcriptional initiation at the arc promoter(s) is poor in $E$. coli.
\end{abstract}

\section{INTRODUCTION}

Pseudomonas aeruginosa is usually considered a strict aerobe. It can use nitrate instead of oxygen as a terminal electron acceptor for anaerobic growth (Palleroni, 1984). When oxygen and nitrate are absent, $P$. aeruginosa is capable of slow growth in rich medium with L-arginine as the sole energy source (Vander Wauven et al., 1984). Mutants that cannot grow by fermentation of arginine (arc mutants) are affected in the enzymes of the arginine deiminase pathway or in unknown accessory functions. The arginine deiminase pathway consists of three enzymes: arginine deiminase (ADI), catabolic ornithine carbamoyltransferase (cOTC), and carbamate kinase (CK), which are the products of the chromosomal $\operatorname{arcA} A \operatorname{arcB}$, and $\operatorname{arc} C$ genes, respectively (Mercenier et al., 1982; Vander Wauven et al., 1984). These enzymes convert Larginine to L-ornithine and generate $1 \mathrm{~mol}$ ATP per mol arginine. Oxygen limitation and arginine together produce strong coordinate induction of the deiminase pathway enzymes; conditions of energy depletion also have an inductive effect (Mercenier et al., 1980). Under aerobic conditions, the arc mutants are able to utilize $\mathrm{L}$-arginine normally as the $\mathrm{C}$ and $\mathrm{N}$ source via other pathways (Haas et al., 1984a).

\footnotetext{
Abbreviations: ADI, arginine deiminase; cOTC, catabolic ornithine carbamoyltransferase; CK, carbamate kinase; OS, minimal medium; YEA, yeast extract/arginine medium.
} 
Catabolic enzymes acting as a functional unit are often specified by clustered genes in Pseudomonas (Haas, 1983). The gene arrangements of several degradative Pseudomonas plasmids have been studied in molecular detail. Much less is known about the organization of chromosomal genes in Pseudomonas (Holloway, 1984). Previously, we have shown that the $\operatorname{arcA\text {,}}$ $\operatorname{arcB}$, and $\operatorname{arcC}$ genes are highly cotransducible (Vander Wauven et al., 1984) and that transposon Tn5-751 insertions causing an $\mathrm{Arc}^{-}$phenotype are clustered in a chromosome segment of about $3 \mathrm{~kb}$ (Haas et al., 1984b; Rella et al., 1985). The arc genes adjacent to the Tn5751 insertions have been isolated on recombinant plasmids with Escherichia coli as the host (Rella et al., 1985). We have now used two of these hybrid plasmids to reconstruct in vitro the entire $\operatorname{arcABC}$ cluster. The cloned $\operatorname{arc} A B C$ genes appear to be contiguous and organized as an operon; their regulation by oxygen limitation and arginine was observed in $P$. aeruginosa but not in $E$. coli.

\section{METHODS}

Bacterial strains and plasmids. They are listed in Table 1. Plasmids constructed in this study are shown in Figs 1 and 2. Recombination-deficient (rec-102) derivatives of arc mutants were constructed by the method of Früh et al. (1983).

Media and culture conditions. The complete yeast extract/arginine (YEA) medium and the minimal (OS) glutamate/arginine medium for anaerobic or oxygen-limited growth of $P$. aeruginosa have been described (Vander Wauven et al., 1984). The media and antibiotic concentrations used in genetic experiments were the same as previously given (Itoh et al., 1984; Haas et al., 1984a; Jeenes et al., 1986). P. aeruginosa cultures were grown at $37^{\circ} \mathrm{C}$ on a rotary shaker (180 r.p.m.). Good aeration was achieved in baffled Erlenmeyer flasks; cells were collected in the exponential phase. Oxygen limitation was obtained in hermetically closed $125 \mathrm{ml}$ bottles containing $60 \mathrm{ml}$ medium; after an initial phase of aerobic growth cells were depleted of oxygen and harvested in the stationary phase after $36 \mathrm{~h}$ incubation. Complementation tests of arc mutants were done on YEA plates incubated in a GasPak anaerobic jar (Vander Wauven et al., 1984).

Enzyme assays. $E$. coli extracts were prepared by sonication and $P$. aeruginosa cells were permeabilized with toluene for enzyme assays as described by Haas et al. (1979). ADI (EC 3.5.3.6) was measured in $1.0 \mathrm{ml} 0 \cdot 1 \mathrm{M}$ sodium citrate buffer pH 5.5 with $10 \mathrm{~mm}$-L-arginine. After the reaction, $1.0 \mathrm{ml} \mathrm{l} \mathrm{M-HCl}$ and $1.0 \mathrm{ml}$ colour reagent $\left[3 \%(\mathrm{w} / \mathrm{v})\right.$ diacetylmonoxime in ethanol $/ \mathrm{H}_{3} \mathrm{PO}_{4} / \mathrm{H}_{2} \mathrm{SO}_{4}, 2: 9: 3$, by vol.] were added and citrulline production was determined as previously described (Haas et al., 1979). The assays for cOTC (EC 2.1.3.3) and CK (EC 2.7.2.2) were done by published methods (Haas et al., 1979; Mercenier et al., 1980). Enzyme specific activities fluctuated by a factor of $\leqslant 2$ in individual experiments; in induced cells, the fluctuations were mainly due to differential enzyme stability and variations in the cellular energy state at harvest. For ADI, cOTC and CK, 1 unit is defined as the amount of enzyme forming $1 \mu$ mol product $h^{-1} . \beta$-Galactosidase (EC 3.2.1.23) activity was measured in arbitrary units defined by Miller (1972). Protein concentrations were determined by a modified Lowry procedure (Vander Wauven et al., 1984).

DNA manipulations. Plasmid DNA was purified as described by Itoh et al. (1984). Small-scale plasmid preparations were obtained by the rapid boiling method (Holmes \& Quigley, 1981), followed by phenol and chloroform extraction. In subcloning experiments DNA fragments were purified from agarose gels essentially by the method of Dretzen et al. (1981); instead of DEAE paper the NA-45 DEAE membrane (Schleicher \& Schuell) was used. DNA fragments were eluted from the membrane by $250 \mu \mathrm{l}$ high-salt buffer $(1 \mathrm{M}-\mathrm{NaCl}, 20 \mathrm{mM}-\mathrm{Tris} / \mathrm{HCl}$ $\mathrm{pH} 8 \cdot 0,0 \cdot 1 \mathrm{~mm}$-EDTA) at $65^{\circ} \mathrm{C}$ for $1 \mathrm{~h}$. The membrane was washed with a further $50 \mu \mathrm{l}$ high-salt buffer and the eluate was centrifuged for $15 \mathrm{~min}$. The supernatant was diluted to $0.5 \mathrm{M}-\mathrm{NaCl}$ and passed through a $100 \mu \mathrm{IDEAE}-$ cellulose column, which was washed with $3 \times 1 \mathrm{ml}$ column buffer $(20 \mathrm{~mm}$-Tris/HCl pH 8.0, 2.5 mM-EDTA). DNA fragments were eluted with $800 \mu \mathrm{l}$ column buffer containing $2 \mathrm{M}-\mathrm{NaCl}$ and recovered by ethanol precipitation. Conditions for restriction, ligation, 'fill-in' reaction with Klenow DNA polymerase I, and transformation of $E$. coli and $P$. aeruginosa, have been given (Itoh et al., 1984). All cloning experiments were done in $E$. coli strains (Table 1). $\mathrm{LacZ}^{+}$constructs were visualized on $\mathrm{X}-\mathrm{Gal}$ (5-bromo-4-chloro-3-indoxyl- $\beta$-D-galactoside) nutrient agar (Miller, 1972).

Construction of $\mathrm{Arc}^{+}$recombinant plasmids and their introduction into P. aeruginosa. An $\mathrm{R}^{68} .45^{\prime} \mathrm{HisII}^{+} \mathrm{Arc}^{+}$ plasmid (our unpublished results) was partially digested with $X$ hol and ligated with XhoI-cut pKT240, giving pME100 (Fig. 2). All other Arc ${ }^{+}$recombinant plasmids were derived from pME163 (Haas et al., 1984b) and pME171 (Rella et al., 1985) via pME180 or pME183, using E. coli as the host (Fig. 1). The pKT240Arc ${ }^{+}$ recombinants to be tested in $P$. aeruginosa were transferred to $43^{\circ} \mathrm{C}$-grown PAO and PTO strains by transformation (Itoh et al., 1984) or mobilization (Jeenes et al., 1986). 
Table 1. Bacterial strains and plasmids

$P$. aeruginosa strain

PAO1

PA06091

PAO6094

PAO6095

PAO6096

PAO6138

PTO66

PTO6091

PTO6095

PTO6096

E. coli strain

CM236

HB 101

JM105

ED8654

Plasmid

pBR322

pME481

ColE1 : :Tnslac

pJF118EH

pNEO

pKT240

pME163

pME171

pME 100, 183, 188, 190,

191, 192, 197, 235,

239, 244; pKT240lacZ

pME177, 180

pME179, 185, 186,

187,195

pME246
Genotype

Wild-type $(\mathrm{cml}-2)$

met-9011 amiE200 strA

arc-6091 : : Tn5-751

met-9011 amiE200 strA

arc A6094:: Tn5-751

met-9011 amiE200 strA

arcB6095 : : Tn5-751

met-9011 amiE200 strA

arc-6096: : Tn5-751

met-9011 amiE200 arcD6138

his-4 lys-12 ilv-1118 trp-6

pro-82 rec- 102

arc-6091: :Tn5-751 strA rec-102

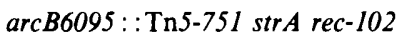

arc-6096: : Tn5-751 strA rec-102

Genotype

$\Delta($ lac pro $A B$ arg $F) \Delta(\arg I)$ thi-l supE recAl srl : : $\operatorname{Tn} 10 \mathrm{r}_{\mathrm{K}}^{-} \mathrm{m}_{\mathrm{K}}$

hsd 20 recA13 proA2 leu-6 thi-1

rpsL20 ara-14 galK2 lac Y1 xyl-5

mtl-1 supE44

thi rpsL end $A$ sbcB15 hsdR4

$\triangle($ lac pro $A B) / \mathrm{F}^{\prime}$ traD 36 pro $A B^{+}$

lac $I^{\circ} \mathrm{Z} \triangle \mathrm{M} 15$

met $B$ supE supF hsdR

Relevant characteristics

$\mathrm{Ap} / \mathrm{Cb} \mathrm{Tc}$

$\mathrm{Ap} / \mathrm{Cb}(\mathrm{pBR} 322 \Delta \mathrm{Tc})$

$\mathrm{Km} \mathrm{lacZ} Y A^{+}$(ColEl with promoter probe $\operatorname{Tn} 5$ derivative)

$\mathrm{Ap} / \mathrm{Cb} \mathrm{acl}^{\mathrm{q}}$ (expression vector with tac promoter)

$\mathrm{Ap} / \mathrm{Cb} \mathrm{Km} / \mathrm{Nm}$ (expression vector with $\operatorname{Tn} 5$ Kan promoter)

$\mathrm{Ap} / \mathrm{Cb} \mathrm{Km} \mathrm{Sm} \mathrm{(IncP-4} \mathrm{broad-host-}$ range vector)

$\mathrm{Ap} / \mathrm{Cb} \operatorname{Tp} \operatorname{ArcA}^{ \pm} \mathrm{B}^{ \pm} \mathrm{C}^{ \pm}$

\}

$\mathrm{Ap} / \mathrm{Cb}$ Tp $\operatorname{ArcA}^{-} \mathrm{B}^{-} \mathrm{C}^{-}$

pKT240 derivatives

pNEO derivatives

\} pBR322 derivatives

pJF118EH derivative
Reference or construction

Holloway (1984)

Haas et al. (1984b)

Rella et al. (1985)

Rella et al. (1985)

Rella et al. (1985)

Vander Wauven et al. (1984)

Früh et al. (1983)

$\mathrm{Met}^{+} \mathrm{Ami}^{+} \mathrm{Rec}^{-}$recombinant of PTO66(R68.45) $\times$ PAO6091*

$\mathrm{Met}^{+} \mathrm{Ami}^{+} \mathrm{Rec}^{-}$recombinant of PTO66(R68.45) $\times$ PAO6095*

$\mathrm{Met}^{+} \mathrm{Ami}^{+} \mathrm{Rec}^{-}$recombinant of

PTO66(R68.45) $\times$ PAO6096*

Source or reference

M. Faelen

N. Willetts

Yanisch-Perron et al. (1985)

Borck et al. (1976)

Source or reference

J. M. Watson

Rella et al. (1985)

Kroos \& Kaiser (1984)

E. Lanka

Pharmacia PL Biochemicals

Bagdasarian et al. (1983)

Haas et al. (1984b)

Rella et al. (1985)

Figs 1 and 2

Fig. 1

Fig. 2

Fig. 2

* Selection for $\mathrm{Met}^{+}$allowed the introduction of the rec-102 marker, which is linked to met-9011 and amiE (Früh et al., 1983).

\section{RESULTS}

\section{Characterization of Tn5-751 insertions in chromosomal arc genes}

In previous work (Haas et al., 1984 ; Rella et al., 1985) four Tn5-751 insertions causing an Arc $^{-}$phenotype have been mapped physically on the $P$. aeruginosa chromosome (Fig. 1). We now examine their effect on the enzymes of the ADI pathway (Table 2). The transposon insertion in strain PTO6091 pleiotropically affected all three deiminase pathway enzymes, which became virtually non-inducible by oxygen limitation. The insertion in strain PAO6094 


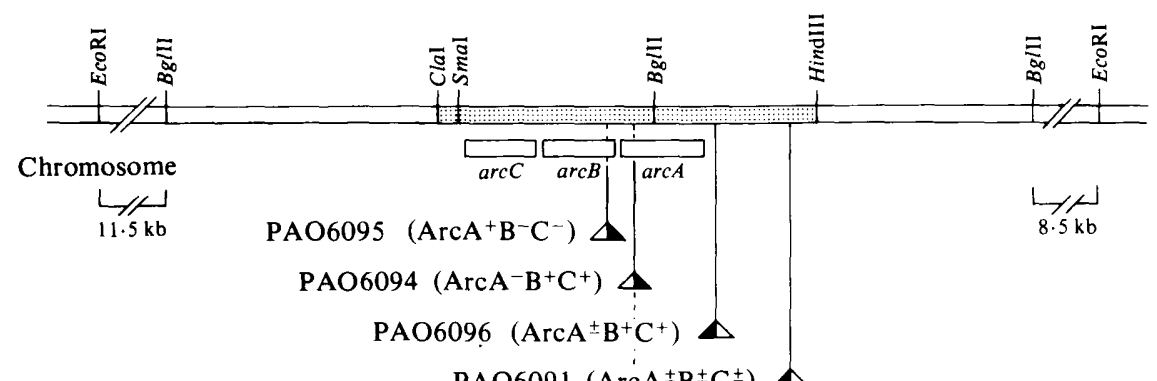

ME171

$\left(\operatorname{ArcA}^{-} \mathrm{B}^{-} \mathrm{C}^{-}\right)$

PAO6091 (ArcA $\left.\mathrm{B}^{ \pm} \mathrm{C}^{ \pm}\right)$
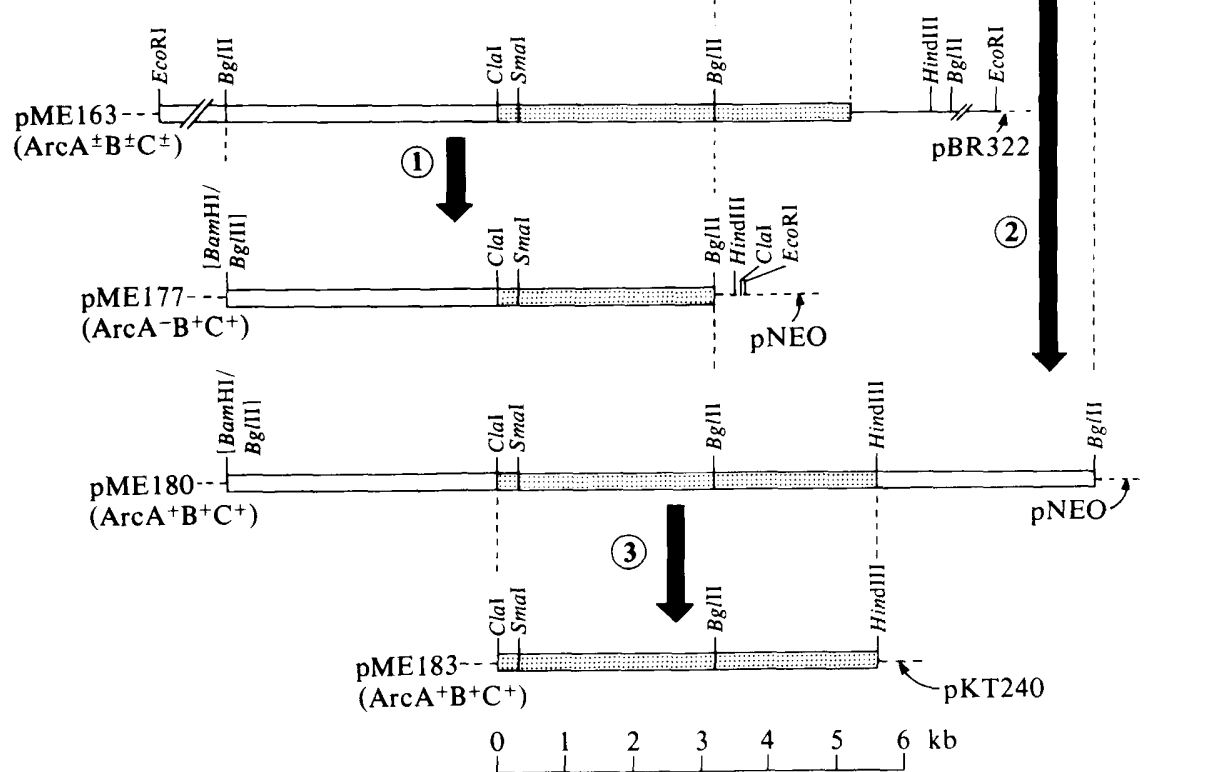

Fig. 1. Effect of chromosomal Tn5-751 insertions on Arc phenotype of $P$. aeruginosa and reconstruction of the functional $\operatorname{arc} A B C$ operon in vitro. The plasmids pME 163 and pME 171 were derived from strains PAO6091 and PAO6094, respectively, by cloning the trimethoprim resistance gene $\left(\mathrm{Tp}^{\mathrm{R}}\right)$ of $\mathrm{Tn} 5-751$ (A ) plus flanking arc sequences (Haas et al., 1984b; Rella et al., 1985). The location of $\operatorname{arcA}$, $\operatorname{arcB}$, and $\operatorname{arcC}$ is taken from Fig. 2. Reconstruction of the $\operatorname{arc} A B C$ operon was done in three steps (heavy arrows, 1-3), as described in the text. Double lines, chromosomal $P$. aeruginosa DNA; single lines, Tn5-75I DNA (IS50R and $\mathrm{Tp}^{\mathrm{R}}$ ); dashed lines, vector plasmid DNA. The dotted area contains the arc operon. The SmaI site in the dotted area is unique; other SmaI sites outside arc are not shown.

inactivated the $\operatorname{arcA}$ gene and had a weak polar effect on $\operatorname{arcB}$. The mutation in strain PTO6095 inactivated $\operatorname{arcB}$ and was strongly polar on $\operatorname{arcC}$. The transposon insertion in strain PTO6096 appears to be outside the arc structural genes but had a polar effect on the induced levels of the arc $A B C$ gene products. The polarity of the Tn5-751 insertions suggests that the gene order is $\operatorname{arcA}-\operatorname{arcB}$-arcC; subcloning experiments (see below) supported this finding.

\section{Reconstruction in vitro of the arc $A B C$ cluster}

Tn5-751 carries determinants for kanamycin and trimethoprim resistance, with a unique EcoRI site between the two resistance markers (Rella et al., 1985). Chromosomal EcoRI 
Table 2. Regulation of the arc operon by oxygen limitation in the presence of arginine

Cells were grown in YEA medium with good $\left(+\mathrm{O}_{2}\right)$ or limiting $\left(-\mathrm{O}_{2}\right)$ aeration and assayed for the arc enzymes. Strains carrying pME183 were tested once; the other values are means of two or three determinations. Note that the PTO strains are $\mathrm{Rec}^{-}$derivatives of the corresponding PAO strains.

\begin{tabular}{|c|c|c|c|c|c|c|}
\hline \multirow[b]{3}{*}{ Strain } & \multicolumn{6}{|c|}{ Specific enzyme activity [units (mg protein) ${ }^{-1}$ ] } \\
\hline & \multicolumn{2}{|c|}{ ADI } & \multicolumn{2}{|c|}{ cOTC } & \multicolumn{2}{|c|}{ CK } \\
\hline & $+\mathrm{O}_{2}$ & $-\mathrm{O}_{2}$ & $+\mathrm{O}_{2}$ & $-\mathrm{O}_{2}$ & $+\mathrm{O}_{2}$ & $-\mathrm{O}_{2}$ \\
\hline PAO1 & 3 & 54 & 60 & 975 & 80 & 525 \\
\hline PTO6091 & 0.2 & 0.6 & 13 & 23 & 80 & 165 \\
\hline PAO6094 & $<0 \cdot 1$ & $<0 \cdot 1$ & 16 & 240 & NT & 790 \\
\hline PTO6095 & 0.7 & 25 & $<5$ & $<5$ & NT & $<10$ \\
\hline PTO6096 & 10 & 8 & 140 & 240 & NT & 250 \\
\hline PTO6091/pME183 & 23 & 410 & 630 & 7200 & NT & 1470 \\
\hline PAO6094/pME 183 & 7 & 360 & 300 & 5400 & NT & 2100 \\
\hline PTO6095/pME183 & 31 & 330 & 450 & 6400 & NT & 1300 \\
\hline PTO6096/pME183 & 25 & 270 & 560 & 5200 & NT & 2200 \\
\hline
\end{tabular}

NT, Not tested.

Table 3. Regulation of the arc operon by arginine during oxygen limitation

Cells were grown in minimal medium OS $+25 \mathrm{~mm}$-L-glutamate with ( $+\mathrm{Arg}$ ) or without ( $-\mathrm{Arg}$ ) $25 \mathrm{~mm}$-L-arginine under conditions of limited aeration. Enzyme assays were done in duplicate.

\begin{tabular}{lcccc}
\multicolumn{1}{c}{ Strain } & $\overbrace{- \text { Arg }}^{\text {ADI }}+$ Arg & $\overbrace{- \text { Arg }}^{\text {cOTC }}$ & Specific enzyme activity [units (mg protein) \\
PAO1 & 30 & 67 & 370 & 1100 \\
PTO6095 & 9 & 26 & NT & NT \\
PTO6095/pME183 & 21 & 125 & 460 & 1400
\end{tabular}

NT, Not tested.

fragments from strains PAO6091 and PAO6094 have been cloned in E. coli with selection for trimethoprim resistance; in the recombinant plasmids pME163 and pME171 (Haas et al., 1984 b; Rella et al., 1985; see Fig. 1) the trimethoprim resistance marker is flanked by arc fragments, which, however, were defective in arc enzyme expression (data not shown). We reconstructed a functional $\operatorname{arc} A B C$ cluster by sequentially cloning the chromosomal $7 \cdot 1 \mathrm{~kb} B g I I I$ fragment of pME 163 and the chromosomal $5.6 \mathrm{~kb} B g / \mathrm{II}$ fragment of pME171 into the $E$. coli vector pNEO, resulting in the $\mathrm{ArcA}^{+} \mathrm{B}^{+} \mathrm{C}^{+}$recombinant pME180 (steps 1 and 2 in Fig. 1). In particular, the correct orientation of both $B g / \mathrm{II}$ fragments in the reconstruction restored the $\operatorname{arcA}$ function. Subcloning of the central $5.6 \mathrm{~kb}$ HindIII-ClaI fragment from pME1 180 into the broad-host-range vector pKT240 cleaved with HindIII + ClaI (step 3 in Fig. 1) gave the recombinant pME183, which complemented the four arc : :Tn5-751 mutants of $P$. aeruginosa for anaerobic growth on arginine.

In $P$. aeruginosa, the arc enzymes encoded by pME183 were inducible by oxygen limitation (Table 2) and by the addition of L-arginine to the growth medium (Table 3). Expression of the chromosomal arc genes is similar (Mercenier et al., 1980; see Tables 2 and 3). In E. coli, by contrast, pME183 specified very low arc enzyme levels (Fig. 2, top line), which were not regulated by energy depletion and arginine (data not shown). Thus, pME183 carries the control region needed for regulation of the $\operatorname{arc} A B C$ genes in $P$. aeruginosa but appears to lack regulatory elements that would allow regulated arc enzyme expression in $E$. coli. 


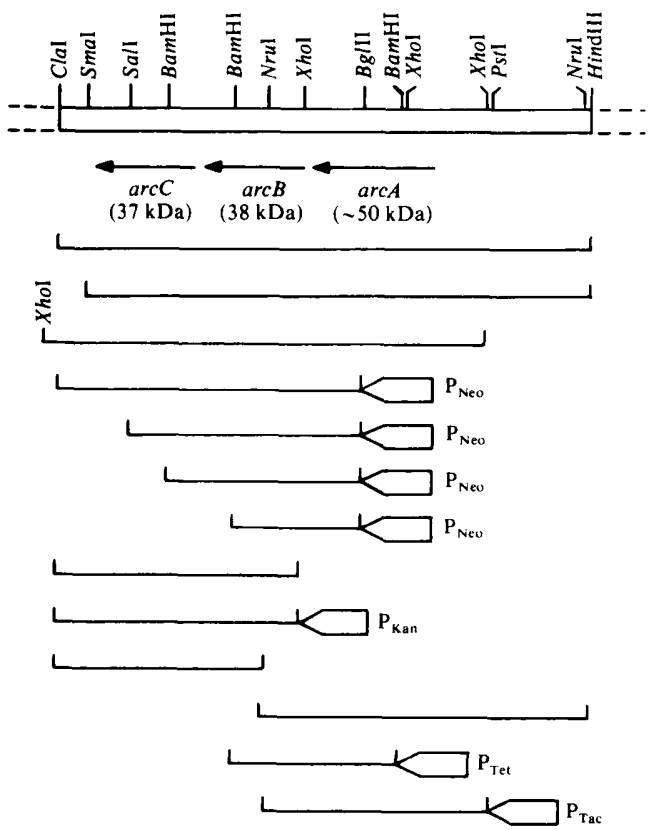

Plasmid Size Vector

Enzyme sp. act.* in $E$. coli CM236 [units (mg protein $)^{-1}$ ]

CK cOTC ADI

$(\mathrm{ArcC})(\mathrm{ArcB})(\mathrm{ArcA})$

\begin{tabular}{|c|c|c|c|c|c|}
\hline pME183† & $17 \cdot 6$ & pKT240 & + & 3 & $0 \cdot 2$ \\
\hline pME190 & $16 \cdot 1$ & pKT240 & + & 4 & $0 \cdot 2$ \\
\hline pME $100 \ddagger$ & $20 \cdot 9$ & pKT240 & + & 3 & 0.2 \\
\hline pME 179 & $7 \cdot 9$ & pBR322 & ++ & 130 & $<0.01$ \\
\hline pME 185 & $6 \cdot 5$ & pBR322 & - & 150 & $<0.01$ \\
\hline pME 187 & $6 \cdot 4$ & pBR322 & - & 70 & $<0.01$ \\
\hline pME 186 & $5 \cdot 7$ & pBR322 & - & $<0.1$ & $<0.01$ \\
\hline pME192‡ & $13 \cdot 8$ & pKT240 & NT & 0.1 & NT \\
\hline pME 188 & $15 \cdot 0$ & pKT240 & ++ & 70 & NT \\
\hline pME191 & $13 \cdot 4$ & pKT240 & - & $<0.1$ & $<0.01$ \\
\hline pME197† & $14 \cdot 0$ & pKT240 & NT & NT & 0.2 \\
\hline pME195 & $6 \cdot 0$ & pBR322 & NT & NT & $<0.01$ \\
\hline pME246 & $7 \cdot 6$ & pJF 118EH & NT & NT & $\begin{array}{c}0.8(- \text { IPTG }) \\
30 \quad(+ \text { IPTG })\end{array}$ \\
\hline
\end{tabular}

$10^{-3} \times \beta$-Galactosidase sp. act. in $P$. aeruginosa (Miller units)

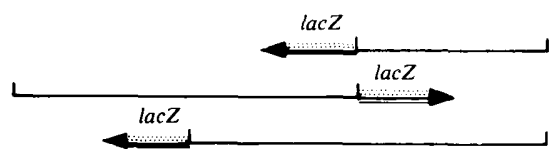

pME235

$17 \cdot 1$

pKT240

$\overbrace{+\mathrm{O}_{2} \S-\mathrm{O}_{2} \S}$

pME239

$21 \cdot 7$

pKT240

4

16

pME244

$18 \cdot 8$

pKT240

5

4

pKT240
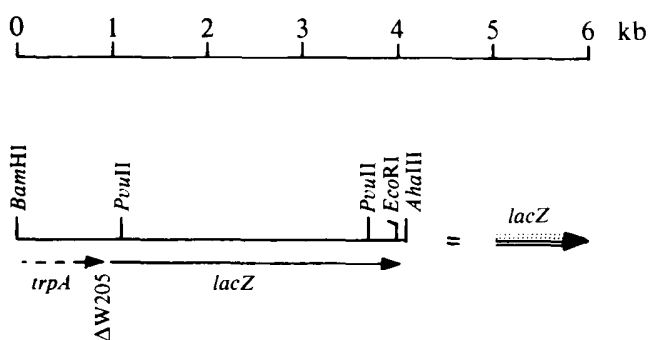

Fig. 2. Localization of the $\operatorname{arc} A B C$ structural genes and determination of the direction of transcription. All recombinant plasmids consisted of the vector plasmids indicated and the inserts of chromosomal DNA shown. The only exception is pME100, which carried an extra random $3.8 \mathrm{~kb}$ chromosomal $X$ hoI fragment upstream of $\operatorname{arcABC}$ (not shown). All plasmids had a selectable ampicillin/carbenicillin resistance determinant. Vector promoters $(a)$ were: $P_{\text {Neo }}$, from the $T n 5$ neomycin/kanamycin resistance (via plasmid pNEO); $\mathbf{P}_{\mathrm{Kan}}$, from the Tn903 kanamycin resistance (on pKT240); $\mathbf{P}_{\mathrm{Tel}}$, from the tetracycline resistance of pBR322; $\mathrm{P}_{\mathrm{Tac}}$, hybrid trp-lac promoter, regulated by the lacI repressor (Bagdasarian et al., 1983). The lacZ promoter probe fragment $(4 \cdot 1 \mathrm{~kb})$ was derived from Tn 5 lac (Kroos \& Kaiser, 1984)

* CK could not be measured accurately because of high blank activities: ++ , activity $>20$; + activity $<20 ;-$, no detectable activity; NT, not tested. IPTG, isopropyl- $\beta$-D-thiogalactoside added at $1 \mathrm{mM}$ to exponentially growing cells for 1 generation.

+ The enzymes encoded by these plasmids were inducible in $P$. aeruginosa.

$\ddagger$ The enzymes encoded by these plasmids were not inducible in $P$. aeruginosa.

$\S+\mathrm{O}_{2}$, well-aerated cultures; $-\mathrm{O}_{2}$, cultures grown with limiting aeration. 


\section{Organization of the arcABC genes}

CK and cOTC of $P$. aeruginosa have been purified; their subunit molecular masses are $37 \mathrm{kDa}$ (Abdelal et al., 1982) and $38 \mathrm{kDa}$ (Legrain et al., 1977), respectively. The ADI of $P$. putida has a subunit of $54 \mathrm{kDa}$ (Shibatani et al., 1978) whereas the ADI of P. aeruginosa has not yet been characterized. When extracts of induced $P$. aeruginosa cells carrying pME183 were subjected to SDS-polyacrylamide gel electrophoresis strong bands of about 38 and $50 \mathrm{kDa}$ were visible; the $50 \mathrm{kDa}$ band was missing from extracts of strain PTO6096/pME235 (ArcA--LacZ+) (data not shown). We tentatively assign the $50 \mathrm{kDa}$ peptide to the $\operatorname{arcA}$ gene. According to the enzyme subunit sizes, the $\operatorname{arcABC}$ structural genes are expected to occupy about $3.5 \mathrm{~kb}$. The three genes were localized on a 3.8 kb segment between the Tn5-751 insertion of strain PAO6096 and the unique SmaI site (Fig. 1), which was used in the construction of pME190 (ArcA $\left.{ }^{+} \mathrm{B}^{+} \mathrm{C}^{+}\right)$(Fig. 2). We conclude that the $\operatorname{arc} A B C$ genes are contiguous.

The gene order was deduced from subcloning experiments performed in $E$. coli. The positions of $\operatorname{arcB}$ and $\operatorname{arc} C$ were defined by pME179, pME185, pME186, pME187, pME188 and pME191 (Fig. 2). The approximate location of $\operatorname{arcA}$ was determined by the analysis of pME100, pME195, pME197, pME235 and pME246 (Fig. 2). Fusion of $\operatorname{arcBC}$ and $\operatorname{arc} A$ fragments to strong vector promoters such as $\mathbf{P}_{\mathrm{Tac}}\left(E\right.$. coli consensus promoter) or $\mathrm{P}_{\mathrm{Neo}}$ (promoter of the $\mathrm{Tn} 5$ kanamycin/neomycin resistance gene) boosted the expression of the corresponding enzymes in E. coli (see pME179, pME188 and pME246; Fig. 2). From this type of experiment and from transcriptional lacZ ( $\beta$-galactosidase) fusions in $\operatorname{arc} A$ (pME235, pME239) and $\operatorname{arcB}$ (pME244), the direction of transcription was deduced to be $\operatorname{arc} \overrightarrow{A B C}$ (Fig. 2). The $4 \cdot 1 \mathrm{~kb}$ lac $Z$ fragment which was used for the transcriptional fusions (Fig. 2) lacks the lac promoter and has only low intrinsic promoter activity in $E$. coli, corresponding to about 200 Miller units of $\beta$-galactosidase (Kroos \& Kaiser, 1984). The same lac $Z$ fragment gave much higher $\beta$-galactosidase levels, 4000 5000 Miller units, in $P$. aeruginosa, independent of the effects of external promoters (as in pKT240lacZ; Fig. 2). The $\beta$-galactosidase specified by the arc-lac $Z$ fusion plasmids pME235 and pME244 was inducible by oxygen limitation in $P$. aeruginosa (Fig. 2). However, because of the accidental Pseudomonas promoter within the lac $Z$ fragment, the $\beta$-galactosidase assays could not be used for a quantitative determination of arc enzyme induction.

There was no evidence for promoters between $\operatorname{arcA}, \operatorname{arcB}$ and $\operatorname{arcC}$. For instance, pME192 specified very low, non-inducible cOTC levels in $P$. aeruginosa and pME191 was devoid of $\operatorname{arc} C$ activity (Fig. 2).

\section{Region upstream of arc $A B C$}

Part of the $1.6 \mathrm{~kb}$ region between the unique HindIII site and the presumptive start of the $\operatorname{arcA}$ gene (Fig. 2) was required for transcriptional initiation and regulation of the $\operatorname{arcABC}$ operon. The first evidence comes from pME100 $\left(\mathrm{ArcA}^{+} \mathrm{B}^{+} \mathrm{C}^{+}\right)$, which carries the $\operatorname{arc} A B C$ structural genes but not a $1 \cdot 1 \mathrm{~kb}$ upstream region present in pME183 (Fig. 2). P. aeruginosa strains PAO6094, PTO6095 and PTO6096 harbouring pME100 expressed high levels of ADI [80 units (mg protein $)^{-1}$ ] and cOTC [1600 units (mg protein) $\left.{ }^{-1}\right]$ under aerobic conditions. These levels were elevated only slightly (about twofold) by oxygen limitation. It seems likely that the region necessary for control by oxygen limitation is not intact in pME100. There is also a possibility that a $3.8 \mathrm{~kb}$ XhoI chromosomal fragment (not shown in Fig. 2), which was inserted accidentally in front of $\operatorname{arc} A B C$ during cloning and which is unrelated to the arc operon, carries a strong promoter overriding the oxygen control of $\operatorname{arc} A B C$ transcription.

Additional evidence for an arc regulatory region comes from the properties of strain PTO6091 (ArcA $\pm \mathrm{B} \pm \mathrm{C} \pm$ ). The $\mathrm{Tn} 5-751$ insertion (Fig. 1) in this non-inducible mutant had a cisdominant effect on arc enzyme expression. This was shown by strain PTO6091 carrying pME244 (ArcA ${ }^{+}$ArcB $^{-}-\mathrm{LacZ}^{+} \mathrm{ArcC}^{-}$; Fig. 2), in which the plasmid-encoded $\beta$-galactosidase (Fig. 2) and ADI were inducible by oxygen limitation, whereas the product of the chromosomal $\operatorname{arcB}$ gene, cOTC, was not. The specific activities [in units (mg protein) ${ }^{-1}$ ] of ADI were 7 (good aeration) and 55 (limiting aeration), and those of cOTC were 14 (good aeration) and 10 (limiting aeration). Furthermore, pME197 (ArcA+B- $\mathrm{C}^{-}$; Fig. 2) did not complement in trans the mutant PTO6091 for anaerobic growth, whereas the $\operatorname{arcA}$ mutant PAO6094 was complemented by 
pME197. We suggest that the Tn5-751 insertion of strain PTO6091 lies within the $\operatorname{arcABC}$ transcriptional unit.

\section{DISCUSSION}

ADI, cOTC and CK are coordinately induced (Mercenier $e$ t al., 1980, 1982); their structural genes are highly cotransducible (Vander Wauven et al., 1984). This indicates that the $\operatorname{arc} A B C$ genes may be organized as an operon. In this study we present evidence that the $\operatorname{arc} A B C$ genes are indeed contiguous and transcribed in the same direction, presumably as a unit. The $1.6 \mathrm{~kb}$ segment upstream of arc $A$ appears to carry control regions which are necessary in cis for regulation by energy depletion and arginine. Additional functions required for anaerobic growth on arginine (e.g. the hypothetical $\operatorname{arc} D$ locus) may also be located there. The $P$. aeruginosa $\operatorname{arc} D$ mutants have wild-type levels of ADI, cOTC, and CK, and yet cannot grow anaerobically on arginine; $\operatorname{arcD}$ mutations are highly cotransducible with $\operatorname{arcB}$ (Vander Wauven et al., 1984). Plasmid pME183 $\left(\mathrm{ArcA}^{+} \mathrm{B}^{+} \mathrm{C}^{+}\right)$restored anaerobic arginine catabolism in the $\operatorname{arcD}$ mutant PAO6138 (data not shown) and therefore appears to carry the $\operatorname{arcD}$ determinant, whose physiological function might be to provide anaerobic arginine transport.

Pseudomonas genes are generally weakly expressed in E. coli (Holloway, 1984; Minton \& Clarke, 1985; Jeenes et al., 1986) and the $\operatorname{arcABC}$ genes are no exception. Assuming a similar copy number for pME183 in E. coli and $P$. aeruginosa, the non-induced ADI and cOTC levels in $E$. coli were about $1 \%$ of those measured in $P$. aeruginosa (Table 2, Fig. 2). Fusion of the arc genes to good $E$. coli promoters strongly enhanced expression of the arc enzymes in $E$. coli. This suggests that the promoter(s) of $\operatorname{arcABC}$ are poorly recognized by the $E$. coli transcription machinery and supports the view that inefficient transcriptional initiation is the principal reason for the low expression of Pseudomonas genes in E. coli (Buckel \& Zehelein, 1981; Minton \& Clarke, 1985; Jeenes et al., 1986).

We thank Marianne Gamper for communication of unpublished results, Patrizia Eppler-Kälin for technical assistance, David Jeenes for critically reading the manuscript and Antje Hitz for typing it. We are grateful to Victor Stalon and Thomas Leisinger for discussion and to E. Lanka and M. Bagdasarian for vector plasmids. This work was supported by a grant of the Swiss Federal Institute of Technology and, in part, by the Swiss National Foundation for Scientific Research (project 3.620-0.84).

\section{REFERENCES}

Abdelal, A. T., Bibb, W. F. \& Nainan, O. (1982) Carbamate kinase from Pseudomonas aeruginosa: purification, characterization, physiological role, and regulation. Journal of Bacteriology 151, 14111419.

Bagdasarian, M. M., Amann, E., Lurz, R., RueckERT, B. \& BAgdaSARIAN, M. (1983). Activity of the hybrid trp-lac(tac) promoter of Escherichia coli in Pseudomonas putida. Construction of broad-hostrange, controlled-expression vectors. Gene 26, 273282.

Borck, K., Beggs, J. D., Brammar, W. J., Hopkins, A. S. \& MURRAY, N. E. (1976). The construction in vitro of transducing derivatives of phage lambda. Molecular and General Genetics 146, 199-207.

BuCKel, P. \& Zehelein, E. (1981). Expression of Pseudomonas fluorescens D-galactose dehydrogenase in E. coli. Gene 16, 149-159.

Dretzen, G., Bellard, M., Sassone-Corsi, P. \& Chambon, P. (1981). A reliable method for the recovery of DNA fragments from agarose and acrylamide gels. Analytical Biochemistry 112, 295298.

Früh, R., Watson, J. M. \& HaAs, D. (1983).
Construction of recombination-deficient strains of Pseudomonas aeruginosa. Molecular and General Genetics 191, 334-337.

HAAS, D. (1983). Genetic aspects of biodegradation by pseudomonads. Experientia 39, 1199-1213.

haAs, D., Evans, R., Mercenier, A., Simon, J.-P. \& Stalon, V. (1979). Genetic and physiological characterization of Pseudomonas aeruginosa mutants affected in the catabolic ornithine carbamoyltransferase. Journal of Bacteriology 139, 713-720.

haAs, D., Matsumoto, H., Moretti, P., Stalon, V. \& MerCenier, A. (1984a). Arginine degradation in Pseudomonas aeruginosa mutants blocked in two arginine catabolic pathways. Molecular and General Genetics 193, 437-444.

HAAS, D., Cryz, S. J., JR, ITOH, Y., Leisinger, T., Lüthi, E., Mercenier, A., ReimmanN, C., Rella, M., Soldati, L., Watson, J. M. \& Wretlind, B. $(1984 b)$. Some applications of transposon insertion mutagenesis in Pseudomonas. In Génétique des Microorganismes Industriels, pp. 91-111. Edited by H. Heslot. Paris: Société Française de Microbiologie.

Holloway, B. W. (1984). Pseudomonads. In Genetics 
and Breeding of Industrial Microorganisms, pp. 63-92. Edited by C. Ball. Boca Raton, Florida: CRC Press.

Holmes, D. S. \& QuIGLEY, M. (1981). A rapid boiling method for the preparation of bacterial plasmids. Analytical Biochemistry 114, 193-197.

Itoh, Y., Watson, J. M., haAs, D. \& Leisinger, T. (1984). Genetic and molecular characterization of the Pseudomonas plasmid pVS1. Plasmid 11, 206220.

JeEnes, D. J., Soldati, L., Baur, H., Watson, J. M., Mercenier, A., ReimmanN, C., Leisinger, T. \& HAAS, D. (1986). Expression of biosynthetic genes from Pseudomonas aeruginosa and Escherichia coli in the heterologous host. Molecular and General Genetics 203, 421-429.

KroOS, L. \& KaISER, D. (1984). Construction of Tn5 lac, a transposon that fuses lac $Z$ expression to exogenous promoters, and its introduction into Myxococcus xanthus. Proceedings of the National Academy of Sciences of the United States of America 81, 5816-5820.

Legrain, C., Stalon, V., Noullez, J.-P., Mercenier, A., Simon, J.-P., Broman, K. \& Wiame, J.-M. (1977). Structure and function of ornithine carbamoyltransferases. European Journal of Biochemistry 80, 401-409.

Mercenier, A., Simon, J.-P., Vander Wauven, C., HAAS, D. \& Stalon, V. (1980). Regulation of enzyme synthesis in the arginine deiminase pathway of Pseudomonas aeruginosa. Journal of Bacteriology 144, 159-163.

Mercenier, A., Stalon, V., Simon, J.-P. \& HaAs, D. (1982). Mapping of the arginine deiminase gene in
Pseudomonas aeruginosa. Journal of Bacteriology 149, 787-788.

Miller, J. H. (1972). Experiments in Molecular Genetics. Cold Spring Harbor: Cold Spring Harbor Laboratory.

Minton, N. P. \& Clarke, L. E. (1985). Identification of the promoter of the Pseudomonas gene coding for carboxypeptidase G2. Journal of Molecular and Applied Genetics 3, 26-35.

Palleroni, N. J. (1984). Family I. Pseudomonadaceae Winslow, Broadhurst, Buchanan, Krunwiede, Rogers and Smith 1917, 555. In Bergey's Manual of Systematic Bacteriology, vol. 1, pp. 141-219. Edited by N. R. Krieg. Baltimore: Williams \& Wilkins.

Rella, M., Mercenier, A. \& HaAs, D. (1985). Transposon insertion mutagenesis of Pseudomonas aeruginosa with a $\operatorname{Tn} 5$ derivative: application to physical mapping of the arc gene cluster. Gene 33, 293-303.

Shibatani, T., Kakimoto, T. \& Chibata, I. (1978). Subunit and amino acid composition of $\mathrm{L}$-arginine deiminase of Pseudomonas putida. FEBS Letters 96, 389-391.

Vander Wauven, C., Piérard, A., Kley-Raymann, M. \& HAAS, D. (1984). Pseudomonas aeruginosa mutants affected in anaerobic growth on arginine: evidence for a four-gene cluster encoding the arginine deiminase pathway. Journal of Bacteriology 160, 928-934.

YANISCh-PeRron, C., Vieira, J. \& Messing, J. (1985) Improved M13 phage cloning vectors and host strains: nucleotide sequence of the $\mathrm{M} 13 \mathrm{mp} 18$ and pUC19 vectors. Gene 33, 103-119. 